\title{
Fenomena Bunuh Diri Remaja Di Toraja Pada Masa Pandemi
}

\author{
Rannu Sanderan, ${ }^{*}$ Robby Marrung, ${ }^{2}$ Hertina Kalo, ${ }^{3}$ Yosia Tasik Sirante ${ }^{4}$ \\ 1,23,4 Institut Agama Kristen Negeri Toraja \\ *rannusan@gmail.com
}

\begin{abstract}
: the suicide phenomenon in this paper is going to narrate, describe and analyzes the occurrence of several suicides that happened in Toraja (South Sulawesi, Indonesia) which is tends to increase since this last four years (2018-2021). Based on several cases, it can be observed that a person tends to kill her or himself after having personal or family problems, economy, bullying (been slighted or offended). The inclination along this pandemic should be previewed and compared according to the cause of each suicide. There were several cases found, but this paper builds only the description by focusing on two cases as shown in the resulting exposure. The paper concludes that there is the four-psychological reason that caused a youth to kill her or himself: family problems, economic problems, bullying, introverted attitude. And by this analysis, all internal and external stakeholders may emerge the spirituality of frugality, and psychologically to push every educational institution and society for the campaign to stop bullying in all aspect.

Keyword: bullying, economic problmes, education, family, relationship, suicide, youth.
\end{abstract}

\begin{abstract}
Abstrak: hasil penelitian fenomena bunuh diri ini menyajikan, memaparkan dan menganalisis realita meningkatnya kecenderungan bunuh diri yang terjadi di Toraja empat tahun terakhir (2018-2021). Pengamatan didasarkan pada beberapa kasus bunuh diri dan/atau upaya bunuh diri karena berbagai persoalan pribadi atau masalah keluarga, kesulitan ekonomi, serta akibat perundungan. Pendekatan metodik yang digunakan meletakkan kecenderungan yang tampak sepanjang masa pandemi dilihat ulang, serta disalingbandingkan sesuai kondisi kasus masing-masing. Ada beberapa kasus yang ditemukan, namun tulisan yang disajikan dalam penelitian ini lebih berfokus pada dua kasus sebagaimana tersaji dalam hasil penelitian. Penelitian ini menyimpulkan bahwa ditemukan ada empat alasan yang menyebabkan generasi muda memutuskan bunuh diri: masalah keluarga, masalah ekonomi, masalah perundungan, karakter yang pendiam. Kemudian melalui analisis yang dibangun diharapkan seluruh pemangku kepentingan (tanpa kecuali) berupaya kembali menonjolkan spiritualitas keugaharian, dan secara psikologis berupaya mendorong setiap institusi pendidikan dan lembaga kemasyarakatan untuk mengampanyekan penghapusan perundungan dalam berbagai bentuknya.

Kata kunci: perundungan, masalah ekonomi, pendidikan, keluarga, relasi, bunuh diri, generasi muda.
\end{abstract}

\begin{tabular}{llll}
\hline Article History : & Received: 11-04-2021 & Revised: 03-06-2021 & Accepted: 05-06-2021
\end{tabular}




\section{Pendahuluan}

Gejala bunuh diri di kalangan anak dan remaja di Indonesia menunjukkan trend peningkatan dari tahun ke tahun. Fenomena ini baru menjadi perhatian publik sejak 1998. Komisi Nasional Perlindungan Anak (Komnas Anak) dalam laporannya menyatakan bahawa kasus bunuh diri ana dan remaja semakin memprihatinkan. Menurut Arist Merdeka Sirait, Ketua umum Komnas Perlindungan Anak, pencetus tindakan bunuh diri secara dominan memiliki kaitan dengan urusan putus cinta dari kaum remaja, tekanan akibat masalah ekonomi, anak yang hidup dalam lingkungan keluarga yang tidak harmonis serta juga masalah yang dialami anak di sekolah. ${ }^{1}$

Meski tidak terdapat data nasional maupun regional provinsi yang spesifik dalam hal angka bunuh diri, namun jumlah ini menunjukan kecenderungan terus bertambah sampai dengan quartal pertama tahun 2021, khususnya beberapa kasus yang terjadi di Toraja ${ }^{2}$. Tingginya angka bunuh diri anak dan remaja ini tentu sangat memprihatinkan. Apa yang sebenarnya terjadi terhadap dunia anak dan remaja? Mengapa dari tahun ke tahun peristiwa bunuh diri di kalangan anak dan remaja di Indonesia terus meningkat? Apa motif mereka melakukan bunuh diri? Untuk menjawab pertanyaan-pertanyaan tersebut, diperlukan eksplorasi lebih mendalam.

Peristiwa percobaan bunuh diri dan bunuh diri di kalangan remaja juga terjadi di Toraja Utara. Pelaku percobaan bunuh diri dan bunuh diri pada umumnya pelajar pada tingkat SMA. Seorang remaja laki-laki misalnya pada sekitar tahun 2015 melakukan bunuh diri dengan mengikatkan tali pengikat kerbau dilehernya. Adapula kejadian bunuh diri pada tahun 2016 menggemparkan dimana seorang remaja laki-laki yang secara kongitif diakui berkategori pintar di sekolah, gaul berbakat dalam musik, namun diam-diam menggantung diri di kamarnya ketika sedang belajar kelompok di rumahnya. Selain itu menurut informasi dari seorang perawat Rumah Sakit swasta di Rantepao mengatakan bahwa mereka sering merawat pasien percobaan bunuh diri (tentamen suicide) dari kalangan remaja. Tahun 2020 tercatat 30 kasus bunuh diri, dengan jumlah kasus masing-masing 14 kasus di kabupaten Tana Toraja dan 16 kasus di kabupaten Toraja Utara, itupun belum terhitung jumlah kasus percobaan bunuh diri. Sedang di awal tahun 2021 sudah tercatat setidaknya ada 6 kasus. $^{3}$

Pada masa-masa yang lalu perilaku bunuh diri dan percobaan bunuh diri di Toraja jarang terjadi. Biasanya yang melakukan bunuh diri adalah orang dewasa. Namun

\footnotetext{
${ }^{1}$ Twenty Oktavia, "Bunuh Diri Di Kalangan Anak Dan Remaja Indonesia | Kyoto Review of Southeast Asia," October 1, 2012, https://kyotoreview.org/bahasa-indonesia/bunuh-diri-di-kalangan-anak-dan-remajaindonesia/.

2 "Bunuh Diri," Kareba Toraja, accessed March 10, 2021, https://kareba-toraja.com/topic/bunuh-diri/.

3 "Pasangan Kekasih Tewas di Kamar Kos, Kasus Bunuh Diri Keempat Selama Januari 2021 di Tana

Toraja," Tribunnews.com, accessed April 10, 2021, https://www.tribunnews.com/regional/2021/02/01/pasangankekasih-tewas-di-kamar-kos-kasus-bunuh-diri-keempat-selama-januari-2021-di-tana-toraja.
} 
beberapa tahun belakangan ini percobaan bunuh diri dan bunuh diri cenderung makin marak dilakukan oleh kalangan remaja dan remaja awal. Fenomena ini menimbulkan pertanyaan mengenai penyebab terjadinya perilaku radikal remaja untuk mengakhiri hidupnya.

Uraian latar belakang masalah di atas mengerucut pada persolan penelitian yang hendak dirumuskan sebagai berikut: Faktor-faktor apa yang menyebabkan terjadinya bunuh diri dan percobaan bunuh diri khususnya di kalangan remaja di Kabupaten Tana Toraja dan Kabupaten Toraja Utara? Tujuan penelitian ini hendak menggali penyebabpenyebab terjadinya bunuh diri dan percobaan bunuh diri dengan berfokus pada gejala pada kalangan remaja di Toraja.

\section{Metode Penelitian}

Metode yang digunakan dalam penelitian tentang bunuh diri di kalangan remaja di Toraja (kabupaten Tana Toraja dan kabupaten Toraja Utara) adalah metode kualitatif. Metode kualitatif-fenomenologis dipilih karena kemampuan metode ini dalam menghadapi realitas jamak serta metode ini sanggup menyajikan secara langsung hakikat hubungan antar peneliti dan informan. Selain itu, metode ini lebih peka dan dapat lebih menyesuaikan diri dengan berbagai latar depan dan latar belakang pemahaman ${ }^{4}$, dengan demikian sanggup menajamkan gagasan yang diperhadapkan pada berbagai pola nilai yang dijumpai. Pengumpulan data dilakukan melalui teknik observasi, interview dan studi dokumen. Dalam menganalisa digunakan analisis data kualitatif secara deskriptif dikombinasikan dengan teknik historis. Peneliti secara tetap membandingkan satu data dengan data yang lain ${ }^{5}$, kemudian secara tetap melakukan pembandingan sebuah kategori terhadap kategori lainnya.

Penelitian tentang kecenderungan remaja mengambil jalan pintas bunuh diri ini sangat penting dan mendesak untuk senantiasa mendapat perhatian dan diberi dukungan pelaksanaan agar upaya pencegahan dapat dilakukan oleh setiap pihak pemangku kepentingan dalam koordinasi dan sinergi (pemerintah, sekolah, gereja, tokoh masyarakat, pemerhati generasi muda, dll). Fenomena ini dirasakan mulai menjadi ancaman sosial, ${ }^{6}$ khususnya bagi generasi muda Toraja bila tidak segera diupayakan melakukan edukasi dan pencegahan secara bersama-sama. Urgensi memberi tekanan perhatian khusus pada isu ini diharapkan dapat memperoleh modelmodel pembinaan warga yang berbasis nilai kristiani sebagai nilai dasar menghadapi tantangan dan beban hidup masyarakat.

\footnotetext{
${ }^{4}$ Muhammad Farid, Fenomenologi: Dalam Penelitian Ilmu Sosial (Jakarta: Prenada Media, 2018). 90

${ }^{5}$ Bungaran Antonius Simanjuntak and Soejidto Sosrodiharjo, Metode Penelitian Sosial (edisi revisi) (Jakarta: Yayasan Pustaka Obor Indonesia, 2009). 139

${ }^{6}$ Suwardi Endraswara, Metode, Teori, Teknik Penelitian Kebudayaan (Yogyakarta: Pustaka Widyatama, 2006). 209
} 


\section{Hasil Penelitian}

Untuk meneliti pokok persolan bunuh diri di kalangan remaja, maka peneliti mengambil tempat penelitian pada dua kabupaten di Toraja, di mana kecenderungan akhir-akhir ini cukup sering terjadi kasus bunuh diri termasuk bunuh diri (baik anak-anak, remaja hingga orang tua, yang terjadi dalam dua bulan berturut-turut pada semester ini. Peneliti memfokuskan diri untuk mendalami penyebab terjadinya bunuh diri secara lebih terfokus pada remaja pada beberapa kasus terakhir ini. Setelah melakukan observasi dan wawancara dengan orang-orang terdekat dari salah satu kasus korban bunuh diri maka data-data tentang penyebab persoalan bunuh diri di kalangan remaja di Kabupaten Toraja Utara dapat di uraikan sebagai berikut:

\section{Bunuh Diri Seorang Mahasiswa}

Penelitian ini melihat masa pandemi sebagai puncak trend bunuh dini, namun observasi riset dimulai sejak bulan Oktober 2018. Saat itu, seorang mahasiswa semester V pada sebuah perguruan tinggi swasta di Toraja melakukan tindakan mengejutkan yakni bunuh diri. Pemuda ini menggantung dirinya dengan mengikat leher menggunakan seutas tali nilon yang biasa digunakan untuk mengikat kerbau. Jenazahnya ditemukan pada sore hari. Pelaku bunuh diri adalah anak bungsu dari tiga bersaudara. Dia dikenal sebagai seorang anak yang rajin membantu keluarga dan juga orang lain. Dalam keluarga dia adalah anak yang sabar, penurut pada orang tua, serta penyayang dan juga pendiam. Hal yang sama juga dikatakan oleh sahabatnya. Menurut sahabatnya, pelaku bunuh diri adalah seorang sahabat yang baik, ia pendiam namun penuh perhatian. Mereka telah bersahabat sejak kecil hingga mereka sama-sama menjadi mahasiswa dan kuliah di tempat yang sama. Orang tua dari korban bunuh diri telah lama bercerai dan masing-masing sudah berkeluarga lagi. Ketika ibunya pergi merantau, korban tinggal bersama dengan pamannya. Namun setelah ibunya pulang dari perantauan ia tinggal lagi bersama ibu dan kakaknya. Dalam keluarga, korban akrab dengan ibu dan saudaranya. Namun ia segan berbicara dengan ayahnya. Jika menginginkan sesuatu atau membutuhkan uang kuliah, ia akan meminta kepada ayahnya melalui kakaknya. Diketahui bahwa korban sangat akrab dengan kakaknya yang merupakan mahasiswa di perguruan tinggi negeri di Toraja.

Menurut sahabatnya, si korban memiliki seorang pacar, namun pacarnya pergi merantau dan sekitar sudah dua bulan mereka pacaran. Namun sebelum ia melakukan tindakan tersebut ia sempat mengatakan kepada pacarnya bahwa ia sangat takut, ia tidak tahu apa yang akan terjadi pada dirinya nanti, esok dan seterusnya.

Sambil kuliah, ia bekerja membantu pamannya yang memeliharanya waktu masih kecil untuk menggembalakan kerbau. Setiap pulang kuliah, ia bertanggungjawab mencari rumput dan memberi makan kerbau pamannya. Biaya kulianya ditanggung oleh 
ayah dan ibunya, tetapi untuk jumlah yang agak besar, ayahnya yang akan bertanggungjawab dan sekali lagi kakanya yang senantiasa menjadi juru bicara. Meskipun pendiam, korban adalah seorang pemudah yang aktif dalam kegiatan-kegiatan gereja bahkan menjadi anggota pengurus organisasi intra gerejawi. Selain itu, ia juga aktif dalam kegiatan dan organisasi di kampus. Jadi dia sesungguhnya seorang aktifis yang pendiam. Sebelum kasus kejadian bunuh tersebut, ia meminta uang kepada kakaknya untuk memperbaiki motornya. Menurut sahabatnya, motor itu rusak dan sedang diperbaiki di bengkel. Korban pusing memikirkan motonya yang baru saja diperbaiki sekitar satu minggu, tapi sudah rusak lagi. Mungkin hal ini yang membuat dia bingung untuk meminta biaya perbaikan motornya lagi. Motor tersebut sangat ia perlukan untuk ia pakai berangkat ke kampus dan untuk mengurus masalah-masalah yang berkaitan dengan kuliah dan kegiatan organisasi. Ia juga mengeluh kepada kakaknya mengenai masalah uang dan memohon kakaknya untuk memintakan uang kepada ayahnya untuk memperbaiki lagi motornya. Tetapi kakaknya ingin supaya dia sendiri yang berbicara dan meminta sendiri kepada ayahnya. Kakaknya berkata: "mengapa harus saya terus yang memintakan kamu uang? Minta sendiri saja!" sebuah kalimat yang sangat disesali oleh kakaknya, karena kakaknya sesungguhnya bermaksud baik agar si korban dan ayahnya bisa menjalin komunikasi agar mereka akrab sebagaimana ayah dan anak.

Keluarga mengatakan bahwa mereka tidak tahu apa yang menjadi penyebab si korban melakukan tindakan bunuh diri tersebut, karena ia tidak mengatakannya kepada siapapun apa yang menjadi masalahnya karena sehari sebelum kejadian almarhum masih bercanda dengan teman-temanya, masih menelfon dengan kedua kakaknya. Namun ia sempat memasang status di media sosial bahwa kuliahnya yang selama ini ia perjuangkan berakhir dengan sia-sia.

\section{Bunuh Diri Siswi SMA}

Sebuah kasus yang terjadi di daerah Kapala Pitu, Kabupaten Toraja Utara terjadi lagi melalui peristiwa bunuh diri yang dilakukan oleh seorang siswi kelas XII (kls. 3) SMA pada bulan Nopember 2018. Gadis ini, merupakan anak pertama dari Sembilan bersaudara. Korban adalah gadis pendiam dan kurang suka bergaul dengan orang lain; seperti yang juga dikatakan oleh keluarga, tetangga dan teman sebayanya. Si korban bunuh diri tinggal bersama kedua orang tua dan saudara-saudaranya. Menurut keluarga dan tetangga, ia termasuk anak yang malas. Ia juga tidak aktif dalam organisasi di sekolah maupun persekutuan gereja. Setiap pulang sekolah, kegiatan korban hanya beristirahat di rumah, dan jarang pergi ke mana-mana.

Untuk kebutuhan sehari-hari, orang tua membiayai sekolah dan keperluannya. Menurut keluarganya, korban kurang mendapat perhatian dari orang tua karena masih ada delapan orang adik-adiknya yang lebih membutuhkan perhatian. Untuk kebutuhan 
sekolah, atau kebutuhan penting orang tuanya pasti akan memenuhi kebutuhan tersebut. Sesungguhnya orang tuanya memperlakukannya dengan cukup baik, namun belum bisa memberi perhatian yang penuh. Karena jumlah adiknya yang banyak maka kadangkala jika permintaan tidak terlalu penting menurut orang tua maka permintaan tersebut biasa ditolak, seperti ketika korban sebelum melakukan aksi bunuh diri sempat meminta uang dan seekor ayam untuk merayakan ulangtahunnya bersama temantemannya, namun permintaan tersebut ditolak oleh orang tuanya.

Seorang temannya, yang telah mengenal dia sejak bangku SMP mengatakan bahwa korban memiliki pacar yang bekerja sebagai supir dengan inisial E. Sebelum terjadinya peristiwa bunuh diri ini, korban menulis selembar surat yang berisi kekecewaan terhadap pacarnya (E). Isi surat itu adalah: "tolong hukum E, jika tidak, saya sendiri yang akan datang menghukumnya". Kepada temannya, korban pernah menceritakan masalah yang sedang dihadapinya yakni cerita buruk mengenai dirinya bahwa dia hamil padahal cerita itu tidak benar. Sebelum peristiwa bunuh diri, menurut temannya, korban sering sakit dan pindah sekolah karena diejek oleh teman-temannya. Di sekolah barunya, ada juga teman sebayanya yang mengatakan buat apa lagi pindah sekolah sementara kamu sedang hamil. Perkataan dari temannya ini membuat korban merasa tertekan dan sakit hati. Penyebab korban melakukan tindakan bunuh diri menurut keluarga dan sahabatnya adalah karena sakit hati pada orang tua, pacar dan teman sebayanya. Ia sakit hati pada orang tuanya, karena mereka kurang memperhatikannya dan menolak permintaannya untuk merayakan ulangtahunnya di rumah, sementara teman-temannya sudah datang ke rumah dalam rangka merayakan ulangtahunnya. Sementara itu juga, ia sakit hati kepada pacarnya karena pacarnya selalu memaksa dia untuk melakukan hubungan intim dan korban menolaknya, tetapi pacarnya selalu mengancamnya. Korban juga sakit hati kepada teman sebayanya karena menyebarkan fitnah tentang korban dan selalu mencurigai bahwa korban sedang dalam keadaan hamil.

\section{Analisis}

Setelah mendalami persoalan bunuh diri remaja di atas, maka peneliti hendak menganalisa pokok-pokok penyebab bunuh diri tersebut. Sebagaimana diketahui bahwa remaja adalah manusia yang sedang berubah dengan cepat, tetapi mereka bukan orang dewasa. Dikatakan demikian karena remaja berada dalam masa peralihan dari masa kanak-kanak menuju masa dewasa. Gejala bunuh diri bukan hanya menjadi persoalan lokal Toraja, Indonesia, namun juga menjadi persoalan lokal di negara maju seperti Amerika; Suicide is the second-leading cause of death for India youth aged 15-24.7 Masa

\footnotetext{
${ }^{7}$ United States Congress Senate Committee on Indian Affairs (1993- ), Youth Suicide Prevention: Oversight Hearing on the Concerns of Teen Suicide among American Indian Youths (U.S. Government Printing Office, 2005). 203
} 
ini seseorang berada dalam proses pertumbuhan dan perkembangannya yang pada dirinya mengalami berbagai macam perubahan baik secara fisiki maupun secara psikis.

\section{Masalah Keluarga}

Penelitian dalam kasus di atas, menunjukkan bahwa kedua korban memiliki masalah dalam keluarga terutama dengan orang tua. Substansi persoalan ini berkaitan dengan kurangnya komunikasi antara orang tua dengan anak. Anak merasa tidak mendapatkan perhatian dan kasih sayang yang lengkap serta utuh dari orang tuanya ${ }^{8}$.

Kurangnya perhatian dari orang tua dan masalah yang terjadi dalah rumah membuat sebagian dari anggota predator menyimpan kemarahan dalam hatinya dan melampiaskannya di luar rumah dalam bentuk perkelahian. Emosi yang tidak stabil dan cenderung meledak-ledak merupakan ciri dari remaja. Jika keadaan ini tidak diimbangi dengan perhatian dan kasih sayang dari keluarga maka mereka akan menyalurkannya dengan perkelahian dan tawuran. Perbuatan baik dari orang tua akan dapat meyakinkan anak bahwa ia disayangi dan diperhatikan. Sedangkan nasehat atau saran lewat katakata yang indah dari orang tua akan lebih berpengaruh terhadap diri remaja daripada bentakan dan hinaan.

Usia remaja adalah usia dimana seseorang mulai meniru sistem-sistem penilaian dan cara hidup keluarganya dengan keluarga lain. Remaja sudah dapat membandingkan kebebasan diri mereka dan respon-respon mereka dengan kebebasan dan respon dari teman-temannya dan tokoh-tokoh idolanya. Para remaja sedang mengembangkan rasa merdeka dan melatih diri terhadap keinginan baru untuk mempunyai otonomi seperti cara orang dewasa. Dalam banyak hal cara berpikirnya kritis dan kausalitas (hubungan sebab akibat), sehingga apa yang dikatakan dan disampaikan orang tua tidak langsung diterima dan dipercaya oleh anak remaja. Anak remaja mulai mempunyai pandangan dan pendapat tentang segala sesuatu, sehubungan dengan masalah yang sedang terjadi termasuk yang dihadapinya. Apabila orang tua tidak memahami perubahan-perubahan pada diri anaknya, maka dengan mudah saja orang tua menganggap anaknya sebagai pribadi yang suka melawan dan nakal. Bila hal tersebut terjadi akan dapat menghambat tercapainya hubungan yang baik dalam keluarga. Secara khusus komunikasi antara orang tua dan anak.

Masalah tersebut di atas tidak akan terjadi apabila dalam komunikasi antara orang tua dan remaja ada saling memahami serta menerima. Setiap individu harus menghargai sesamanya, harus bersedia mendengar dan mengerti sesamanya. Sebagai orang tua anak, sangat penting untuk menghargai dan memandang anak sebagai pribadi yang berharga dalam kedudukannya sebagai anak, sehingga apapun pendapatnya dan yang dilakukannya dianggap penting dan bernilai. Orang tua sebagai yang bertanggung jawab

\footnotetext{
${ }^{8}$ Naomi Sampe, "Meretas Kecakapan Komunikasi Interpersonal Keluarga Kristen Memasuki Era 4.0," BIA': Jurnal Teologi Dan Pendidikan Kristen Kontekstual 2, no. 1 (June 24, 2019): 72-82, https://doi.org/10.34307/b.v2i1.84.
} 
terhadap anaknya, harus memberi perhatian serta mempertimbangkan dengan sungguh-sungguh apa yang anak katakan dan lakukan. ${ }^{9}$

Pada masa remaja terjadi juga perkembangan intelektual untuk mendapatkan identitas diri. Perkembangan intelektual ini berkenaan dengan fungsi psikis untuk mencari tahu. Masa tersebut remaja memiliki rasa ingin tahu yang besar, oleh karena itu ia terdorong untuk mencari ilmu pengetahuan.dan pengalaman-pengalamn baru. Remaja ingin selalu melepaskan diri dari ketergantungannya kepada orang tua dan rasa aman dari keluarga. Ia ingin selalu meninggalkan keluarga dengan mencari pengalamanpengalaman sendiri melalui cara hidup sendiri. Selain hal tersebut. Perkembangan emosi pada diri seorang remaja sangat terkenal. Hal ini disertai dengan perilaku "pemberontakan" dan "melawan ortu". Persoalan pertentangan dan perselisihan paham yang sering terjadi dan tidak terselesaikan di rumah dapat "memaksa" seseorang remaja untuk mencari ketenangan di luar rumah sebagai solusinya. Dengan melakukan hal tersebut, maka remaja merasa memperoleh kebebasan emosional.

\section{Masalah Ekonomi}

Persepektif ekonomi menjadi pencetus lain dari persoalan remaja yang acapkali membuat mereka berpikir pendek ${ }^{10}$, sebagaimana dapat juga dilihat pada kasus di atas. Informasi yang diperoleh memperlihatkan adanya kekecewaan korban karena tidak mendapat pemenuhan kebutuhan dalam hal keuangan, dalam kasus ini adalah untuk memperbaiki motor dan untuk berulangtahun. Masalah kendaraan dan perayaan ulangtahun bagi orang tua tidak terlalu urgen, tetapi bagi remaja, hal ini adalah bagian dari pencitraan identitas mereka. Tidak terpenuhinya kebutuhan ini dapat membuat mereka kecewa, marah dan sulit mengendalikan emosinya.

Remaja terkenal dengan emosinya yang meluap-luap, karena adanya pengaruh hormon didalam dirinya. Perasaan remaja dengan cepat berganti, Suatu saat merasa gembira, tetapi tiba-tiba biasa menjadi murung dan kurang bersemangat. Pada masa remaja seseorang umumnya dikuasai oleh pikiran emosinya. Hal ini memang benar jika dibandingkan dengan anak-anak, remaja lebih banyak memikirkan sesuatu. Dalam masa ini seseorang mulai juga memikirkan kehidupan secara mandiri, baik secara sosial, ekonomis maupun politis dengan mengutamakan kebebasan dari pengawasan ketat orang tua.

Perubahan pada diri remaja tidak hanya meliputi aspek fisik, tetapi juga aspek psikisnya. Yang terjadi akibat perubahan psikis misalnya: kegelisahan yaitu keadaan tidak tenang menguasai diri remaja. Saat itu remaja mempunyai banyak keinginan,

\footnotetext{
${ }^{9}$ Sampe.

${ }^{10}$ JK-LPK, Anak dan lembaga pelayanan Kristen: pergumulan LSM Kristen dalam menangani \& mengangkat persoalan anak ke tengah isu pembangunan (Jakarta: Jaringan Kerja Lembaga Pelayanan Kristen di Indonesia, 1997). 209
} 
mereka ingin mencoba segala sesuatu yang baru, contohnya: model pakaian, ingin punya motor walaupun orang tua tidak mampu, dan lain-lain. Keinginan-keinginan seperti itulah yang sering membuat seseorang menjadi gelisah dalam kehidupannya. Secara sosiokultural, penanaman nilai dan pengutamaan norma bersyukur dalam keugaharian perlu diintegrasikan secara utuh dengan penilaian pada perubahan lingkungan sosial dan ekonomi yang terus terjadi. ${ }^{11}$

\section{Masalah Perundungan/Bullying}

Perundungan justru lebih banyak dialami anak dalam lingkup pergaulan mereka sendiri. Namun tanpa disadari perjumpaan seorang anak dengan anak lain yang lebih superior, nakal dan/atau acapkali membuatnya inferior dan rentan perundungan ${ }^{12}$. Sekolah juga merupakan media terjadinya perundungan. Pergaulan dengan teman sebaya merupakan suatu kebutuhan penting bagi anak dan remaja ${ }^{13}$. Kelompok-kelompok teman sebaya (peer group) adalah suatu hal yang sangat wajar dan normal bagi remaja. Mereka membutuhkan kelompok-kelompok teman sebayanya sebagai sarana aktualisasi diri, sosialisasi dan tempat menumpahkan kekecewaan mereka.

Remaja sangat ingin dipandang sebagai pribadi yang mandiri. Mereka ingin turut bertanggungjawab tetapi tidak rela ditindas dan dipaksa melakukan hal-hal yang tidak disenanginya. Mereka ingin dilibatkan dalam mengambil suatu keputusan bersama ${ }^{14}$ dan hal ini dapat mereka temui dalam kelompok geng atau peer. Pada umumnya remaja lebih banyak menerima norma moral berdasarkan penerimaan atau penghargaan dari teman-teman maupun kelompok diluar rumah. Meskipun demikian masalah pengertian, penghargaan dan penerimaan dari pihak-pihak yang dekat, khususnya keluarga tetap sangat mereka butuhkan dalam menghadapi keadaan tidak stabil tersebut.

Dalam masa remaja kecenderungan membentuk kelompok dan kegiatan kelompok dapat terjadi. Hal ini dapat dilakukan oleh para remaja dengan alasan mencari solusi bersama atas masalah yang dihadapinya. Jika hal ini terjadi pada anak remaja, maka sebagai orang tua anak tidak boleh tinggal diam, tetapi harus selalu mengontrol dan mengarahkan anaknya. Apabila dalam kelompok pergaulan mereka muncul kekuatan yang disalurkan secara negatif dan destruktif, maka dapat dicegah dan disalurkan secara positif oleh orang tua.

\section{Karakter}

${ }^{11}$ Douglas Hollan, "Indignant Suicide in the Pacific: An Example from the Toraja Highlands of Indonesia," Culture, Medicine and Psychiatry 14, no. 3 (September 1990): 365-79, https://doi.org/10.1007/BF00117561.

${ }^{12}$ Arina Mufrihah, "Perundungan Reaktif di Sekolah Dasar dan Intervensi Berbasis Nuansa Sekolah," Jurnal Psikologi 43, no. 2 (June 1, 2016): 135-53, https://doi.org/10.22146/jpsi.15441.

${ }^{13}$ Ana Widyastuti Kons M. Pd, 77 Permasalahan Anak dan Cara Mengatasinya (Jakarta: Elex Media Komputindo, 2020).

${ }^{14}$ Binsen Samuel Sidjabat, Mengajar secara profesional: mewujudkan visi guru profesional (Bandung: Yayasan Kalam Hidup, 2008). 147-149 
Kedua pelaku bunuh diri, memiliki karakter pendiam dan tidak banyak bicara. Pada umumnya karakter pendiam, lebih suka menyimpan masalahnya sendiri dan tidak menceritakannya kepada orang lain. Remaja pendiam kadangkala menyelesaikan dan lari dari persoalannya dengan menghayal dan berfantasi.

Menghayal dan berfantasi adalah merupakan ciri-ciri bagi seorang remaja. Khayalan dan fantasi pada remaja putra banyak berkisar mengenai prestasi dan tangga karier. Sedangkan pada remaja putri terlihat lebih banyak sifat perasa, sehingga berintikan romantika hidup. Khayalan dan fantasi tidak selalu bersifat negatif, karena dipihak lain dianggap sebagai suatu pelarian dari situasi dan suasana yang tidak memuaskan remaja. Khayalan atau fantasi dapat juga bersifat positif sebagai suatu penghematan untuk daya kreativitasnya yang tiak memerlukan biaya. Lewat khayalan dan fantasi yang positif dan konstruktif yang diciptakan oleh generasi muda, akan menghasilakan banyak hal serta ide baru dalam kehidupan sang remaja.

\section{Masalah Dengan Pacar}

Seseorang dikatakan sudah remaja apabila mereka menunjukkan gejala dengan adanya perubahan-perubahan jasmani (fisik), yang menunjukkan adanya kematangan seksual. Apabila hal ini sudah terjadi pada seseorang, maka akan muncul pada dirinya suatu perhatian terhadap lawan jenis. Selain hal tersebut, akan ada juga proses perkembangan psikis. Dalam hal ini remaja mulai membangun relasi denga lawan jenis yang mereka sukai.

Pada tahap remaja sudah timbul perasaan suka pada seseorang yang mereka sebut pacar atau kekasih. Kadang hubungan ini berjalan dengan lancar namun tidak jarang juga menjadi rumit dan membuat remaja stress. Salah satu masalah yang sering muncul dalam hubungan pacaran remaja adalah masalah seksual. Apalagi jika si remaja berpacaran dengan seorang yang lebih dewasa dari dirinya. Si remaja yang belum cukup dewasa dan masih dibawah pengawasan orang tua tentu saja tidak diperbolehkan untuk melakukan hubungan seksual dengan pacarnya. Selain tidak sesuai dengan norma agama, juga tidak pantas secara sosial. Selain itu si remaja belum dapat diizinkan untuk menikah karena masih dalam studi. Hal inilah yang terjadi pada salah satu kasus bunuh diri seorang siswi SMA yang terjadi di Kapala Pitu Kabupaten Toraja Utara.

\section{Mengupayakan Pendidikan Anak Berbasis Kasih Dalam Keluarga}

Mendidik anak berdasarkan kasih menghargai dan memandang anak sebagai gambar Allah yang utuh. Anak-anak yang dididik dalam kasih akan bertumbuh sebagai pribadi yang menghargai dan menerima diri sendiri maupun orang lain seutuhnya dengan 
kelebihan dan kekurangannya ${ }^{15}$. Mereka akan menjadi pribadi matang dan bijaksana serta mengasihi. Langkah-langkah konkrit mendidik anak dalam kasih diuraikan berikut ini:

\section{Mendidik Tanpa Pilih Kasih}

Pola pendidikan yang pilih kasih dapat dilihat dalam kehidupan keluarga Ishak, yang membeda-bedakan pemberian kasih sayang kepada anak-anaknya dan menyebabkan dendam dan kebencian serta rencana pembunuhan Esau terhadap saudaranya Yakub (bnd. Kejadian 27:41), sehingga rumah tangga ini terpecah menjadi dua kubu dan tidak ada lagi kesatuan di dalam keluarga.

Setiap anak dalam keluarga berhak memperoleh kasih sayang dari orang tuanya. Sikap atau perbuatan orang tua yang membeda-bedakan perlakuan kasih sayang untuk anak-anaknya akan menimbulkan hubungan yang tidak sehat, pertentangan di antara anak-anak, suasana rumah tangga yang tidak harmonis serta anak tidak dapat mengembangkan kasih sayang terhadap saudara-saudaranya. Anak yang kuat akan berkembang menjadi anak yang otoriter dan anak yang lemah berkembang menjadi anak yang licik. Disamping itu anak yang kurang mendapat kasih sayang akan merasa disisihkan dan "minder". Oleh sebab itu di dalam setiap keluarga seharusnya tidak ada konsep atau praktik "anak emas".

\section{Menerima dan Menghargai Anak}

Pada dasarnya seorang anak membutuhkan penerimaan dan penghargaan yang tulus tanpa syarat, mereka diterima dan dihargai bukan hanya karena mereka memperoleh atau melakukan hal-hal tertentu sesuai dengan yang diharapkan. Anak sebagai manusia yang bermartabat ingin dicintai, dihormati, dihargai sekaligus ingin menghormati, mencintai dan menghargai. Anak adalah subjek bukan objek yang dapat diperlakukan semata-mata berdasarkan kehendak orang tua. Sebagai subjek anak membutuhkan perlakukan dan bantuan untuk mengenal dirinya sebagai pribadi sesuai dengan harkat dan martabat kemanusiaannya.

Penerimaan dan penghargaan ini sangat penting untuk mengembangkan atau memupuk harga diri anak. Sikap orang tua sangat berpengaruh dalam membentuk harga diri anak. Orang tua hendaknya menghindari hal-hal yang dapat merusak atau menghambat harga diri anak, misalnya, kecaman-kecaman, caci-maki, mencap anak dengan sebutan yang merendahkan seperti, "goblok", "konyol" atau "malas". Perlakuan seperti ini menghambat harga diri positif dari anak. Orang yang memiliki harga diri yang tinggi (sehat) mengenal dan menerima dirinya sendiri dengan segala keterbatasannya,

\footnotetext{
${ }^{15}$ Rannu Sanderan, "Heuristika dalam Pendidikan Karakter Manusia Toraja Tradisional," BIA': Jurnal Teologi dan Pendidikan Kristen Kontekstual 3, no. 2 (December 19, 2020): 306-27, https://doi.org/10.34307/b.v3i2.213.
} 
tidak merasa malu dengan keterbatasannya bahkan mengakui dan menghargai kelebihan dan keunggulan orang lain. ${ }^{16}$

\section{Mengenali Keunikan Anak}

Setiap anak memiliki ciri yang khas dan unik serta mempunyai kelemahan dan kelebihan tersendiri. Selain itu anak-anak mempunyai motivasi, watak dan kepandaian yang tidak sama, Perbedaan-perbedaan tersebut disebabkan oleh faktor hereditas anak dan lingkungan dimana ia tumbuh dan dibesarkan.

Anak berkembang sesuai dengan kekhasan dan keunikannya. Keunikan anak perlu diketahui, agar anak tersebut dapat diarahkan sesuai dengan kekhasan, watak dan bakatnya. Anak perlu diberi kesempatan seluas-luasnya untuk menyalurkan dan mengembangkan diri sesuai dengan keunikannya. Anak yang diberi kesempatan untuk mengembangkan potensi (bakat) yang ada pada dirinya sejak kecil dapat menjadi orang terampil dan diandalkan. Melarang atau menghalangi anak berkembang sesuai dengan kekhasan watak dan bakatnya dapat menghancurkan anak-anak sejak dini. Agar anak dapat berkembang sesuai dengan bakat, potensi dan cita-citanya, keunikan harus diberi tempat dan dicarikan peluang untuk diperkembangkan. ${ }^{17}$ Disamping itu, membandingbandingkan anak juga harus dihindari. Anak yang dibanding-bandingkan dengan anak lain akan mengakibatkan ia merasa direndahkan, tidak percaya diri, dan tidak senang pada dirinya sendiri. Juga dapat menyebabkan rasa iri dan jengkel pada anak yang dibanding-bandingkan dengan dirinya.

\section{Disiplin Demokratis}

Disiplin merupakan hal yang urgen dalam mendidik anak. Melalui disiplin sikap, anak dapat dibentuk melalui pemberian dorongan terhadap tingkah laku yang baik dan perbaikan terhadap tingkah laku yang salah. Ada tiga unsur penting dalam disiplin yaitu: peraturan, hukuman dan hadiah. Ketiganya berfungsi sebagai pedoman, ganjaran terhadap pelanggaran dan penguatan terhadap perbuatan baik. ${ }^{18}$

Alkitab menekankan pentingnya disiplin yang penuh kasih. Dalam Kolose 3:12 dikatakan: "Hai bapa-bapa jangan sakiti hati anakmu supaya jangan tawar hatinya". Paulus memperingatkan orang tua agar tidak melakukan tindakan-tindakan yang esktrim yang dapat berakibat buruk bagi perkembangan mental anak-anak mereka. Dengan demikian penerapan disiplin harus diimbangi dan didasari dengan kasih yang tanpa syarat (kasih agape). Kasih mendorong orang tua menerapkan disiplin demokratis dan menghindari disiplin yang otoriter. Disiplin yang sehat (demokratis) akan

\footnotetext{
${ }^{16}$ Patricia H. Berne, Membangun harga diri anak (Yogyakarta: Penerbit Kanisius, 1988). 13-17

${ }^{17}$ Sumardiono, Homeschooling : Lompatan Cara Belajar (Jakarta: Elex Media Komputindo, 2007). 154

${ }^{18}$ Elizabeth Bergner Hurlock, Psikologi perkembangan: suatu pendekatan sepanjang rentang kehidupan (Jakarta: Penerbit Erlangga, 1990). 124
} 
menumbuhkan penghargaan dan rasa hormat terhadap otoritas dalam diri anak, memperbaiki hubungan dengan orang tua dan menunjang terhadap harga diri yang sehat. Sebaliknya disiplin yang otoriter dapat membawa pengaruh buruk bagi perkembangan anak.

Sekarang ini terdapat tiga cara yang umum digunakan untuk mendisiplinkan anak yakni, disiplin otoriter, disiplin lemah dan disiplin demokratis. Orang tua yang mendisiplinkan anaknya dengan otoriter cenderung kurang menghargai hak-hak anak, tidak ada penjelasan kepada anak tentang maksud dari aturan-aturan yang dibuat, tidak perlu ada hadiah karena telah mematuhi peraturan, hal ini sudah menjadi kewajiban. Dalam disiplin yang lemah tidak diajarkan peraturan-peraturan juga tidak ada hukuman dan hadiah, yang didasarkan pada anggapan bahwa melalui akibat dari perbuatannya sendiri anak akan berperilaku sosial. Disiplin yang demokratis lebih menekankan prinsip-prinsip demokratis. ${ }^{19}$

Disiplin demokratis sedapat mungkin menghindari hukuman yang mengandung unsur-unsur kekerasan. Hukuman bukan untuk melampiaskan rasa dendam atau kemarahan atas perilaku buruk anak, juga bukan untuk menunjukkan kekuasaan orang tua kepada anak. Hukuman tersebut harus konstruktif, dimaksudkan untuk memperbaiki kelakuan anak sehingga nilai-nilai positif perilaku anak meningkat, misalnya anak yang mengotori lantai diberi hukuman untuk menyapu. Hukuman harus disesuaikan dengan pelanggaran yang dilakukan anak dan menghindari unsur kekerasan misalnya, menghina, membanding-bandingkan, menyiksa, mengabaikan keunikan anak dan ucapan serta perlakuan yang dapat berdampak negatif bagi perkembangan anak. Disiplin disesuaikan dengan usia anak, atau tingkat perkembangan dan keunikan anak. Untuk menguatkan perbuatan atau perilaku anak yang baik perlu diberikan penghargaan melalui pemberian hadiah terutama pujian dan pengakuan sosial.

Hubungan kasih sayang yang sehat antara orang tua dan anak memudahkan pemberian hadiah dan hukuman yang sepadan. Anak juga akan lebih mudah menerima nilai-nilai dari orang tuanya. Sangat penting bagi orang tua meluangkan sebagian dari waktunya untuk menikmati kebersamaan dengan anak-anaknya. Orang tua perlu memahami bahwa mendisiplinkan anak lebih luas dari hukuman. Mendisiplinkan adalah proses membentuk moralitas dan perilaku anak-anak yang harus dilakukan hati-hati dan penuh kasih. Anak perlu mengetahui bahwa mereka tetap dikasihi dan disayangi, yang ditolak adalah perilaku atau perbuatannya yang keliru. Dengan demikian anak dapat merasakan dirinya diterima, dihargai dan dikasihi.

Sementara itu anak dilatih hidup teratur, dengan penuh kasih dan berdisiplin dalam kehidupan dengan bantuan keteladanan orang tua. Masa anak adalah masa meniru, itu berarti teladan positif orang tua yang dilihat anak, baik perkataan, perilaku,

\footnotetext{
${ }^{19}$ Hurlock. 123
} 
dan nilai-nilai yang dijunjung orang tua memiliki pengaruh besar terhadap anak. Jika anak menyaksikan atau merasakan adanya kesenjangan antara nasihat, ajaran dengan teladan orang tua, maka anak akan mengalami konflik dalam batinnya. Kualitas gaya hidup orang tua mampu bersuara lebih kuat dan lebih meyakinkan dari segala daya tarik dunia terhadap anak.

\section{Memerhatikan dan Memenuhi Kebutuhan Anak}

Kebutuhan anak meliputi kebutuhan fisik dan psikologis. Kebutuhan psikologis yang meliputi: Kebutuhan rasa aman; Anak memerlukan rasa aman, baik jasmani maupun emosi. Sikap orang tua memegang peranan penting dalam menciptakan suasana dan rasa aman bagi anak. Kebutuhan untuk dimiliki dan dikasihi. Kebutuhan penghargaan diri. Kebutuhan aktualisasi diri; Aktualisasi diri merupakan suatu keinginan yang tertinggi di alam bawah sadar manusia, yang dengan aktif menuntut suatu pengembangan bakat diri, menuntut kebenaran, kebaikan dan keindahan. Seorang anak harus dibantu dalam mengembangkan daya kreasi, daya percaya diri dengan aktif mengembangkan daya alam bawah sadarnya sehingga ia memiliki rasa kepuasan dalam mengaktualisasikan dirinya. Dalam hal ini anak-anak memiliki kebutuhan disiplin dan bimbingan. ${ }^{20}$ Kebutuhan psikis anak sering diabaikan karena kesibukan orang tua atau karena dianggap tidak terlalu penting, padahal kebutuhan psikis merupakan kebutuhan dasar anak, sama pentingnya dengan kebutuhan makan dan minum. Di sinilah dituntut peranan dan tanggung jawab orang tua dalam memenuhi setiap kebutuhan anakanaknya (bnd. I Tim. 5:8).

\section{Kesimpulan}

Berdasarkan hasil penelitian di lapangan yang kemudian dianalisis dengan data pustaka maka penyebab bunuh diri oknum remaja di Kabupaten Toraja Utara adalah sebagai berikut: Pertama, kurangnya perhatian dan kasih sayang dari orang tua, yang diperburuk dengan mandeknya komunikasi antara orang tua dan anak; Kedua, adanya masalah ekonomi berupa tidak terpenuhinya keinginan dari korban. Ketiga, terjadinya bullying yang membuat korban merasa malu, tertekan dan sakit hati; Keempat, kemungkinan dipicu oleh sifat pendiam (introvert) dari si korban bunuh diri tersebut. Sifat pendiam ini membuat korban mengalami kesulitan untuk mengeluarkan dan membagi persoalan yang dihadapinya kepada orang lain. Persoalan yang dipendam sendiri membuat si korban stress sehingga mengambil tindakan bunuh diri. Kelima, masalah hubungan dengan pacar, di mana korban mengalami masalah yang rumit dan mengecewakan dalam hubungan dengan kekasihnya.

\footnotetext{
${ }^{20}$ Chandrawaty et al., PENDIDIKAN ANAK USIA DINI: Perspektif Dosen PAUD Perguruan Tinggi Muhammadiyah (Jakarta: EDU PUBLISHER, 2020). 366
} 
Saran praktis perlu disampaikan kepada setiap orang tua agar meluangkan waktu semaksimal mungkin untuk memberi perhatian dan mendengarkan masalah dari anakanak remaja mereka. Juga usaha keras dari setiap lembaga pendidikan di semua jenjang untuk secara terus-menerus dan terkoordinasi untuk mengarusutamakan kembali spiritualitas keugaharian dan nilai kearifan lokal yang senantiasa bersyukur dalam kesederhanaan. Serta secara khusus dunia pendidikan gencar secara terus-menerus menggalakkan kampanye menghentikan perundukangan dalam berbagai bentuk demi menghindari dan menekan jatuhnya korban-korban bullying yang lain. Kepada pimpinan lembaga atau organisasi Gereja, untuk menjangkau setiap anak remaja dan menanamkan iman yang kokoh kepada mereka untuk menghadapi persoalan-persoalan yang pelik dalam masa transisi remaja ini.

\section{Referensi}

Affairs (1993- ), United States Congress Senate Committee on Indian. Youth Suicide Prevention: Oversight Hearing on the Concerns of Teen Suicide among American Indian Youths. U.S. Government Printing Office, 2005.

Berne, Patricia H. Membangun harga diri anak. Yogyakarta: Penerbit Kanisius, 1988.

Kareba Toraja. "Bunuh Diri." Accessed April 10, 2021. https://karebatoraja.com/topic/bunuh-diri/.

Chandrawaty, Intan Puspitasari, Diah Andika Sari, Badroeni, Hidjanah, Rikha Surtika Dewi, Dewi Eko Wati, et al. PENDIDIKAN ANAK USIA DINI: Perspektif Dosen PAUD Perguruan Tinggi Muhammadiyah. Jakarta: EDU PUBLISHER, 2020.

Endraswara, Suwardi. Metode, Teori, Teknik Penelitian Kebudayaan. Yogyakarta: Pustaka Widyatama, 2006.

Farid, Muhammad. Fenomenologi: Dalam Penelitian Ilmu Sosial. Jakarta: Prenada Media, 2018.

Hollan, Douglas. "Indignant Suicide in the Pacific: An Example from the Toraja Highlands of Indonesia." Culture, Medicine and Psychiatry 14, no. 3 (September 1990): 36579. https://doi.org/10.1007/BF00117561.

Hurlock, Elizabeth Bergner. Psikologi perkembangan: suatu pendekatan sepanjang rentang kehidupan. Jakarta: Penerbit Erlangga, 1990.

JK-LPK. Anak dan lembaga pelayanan Kristen: pergumulan LSM Kristen dalam menangani \& mengangkat persoalan anak ke tengah isu pembangunan. Jakarta: Jaringan Kerja Lembaga Pelayanan Kristen di Indonesia, 1997.

Kons, Ana Widyastuti, M. Pd. 77 Permasalahan Anak dan Cara Mengatasinya. Jakarta: Elex Media Komputindo, 2020.

Mufrihah, Arina. "Perundungan Reaktif di Sekolah Dasar dan Intervensi Berbasis Nuansa Sekolah." Jurnal Psikologi 43, no. 2 (June 1, 2016): 135-53. https://doi.org/10.22146/jpsi.15441.

Oktavia, Twenty. "Bunuh Diri Di Kalangan Anak Dan Remaja Indonesia | Kyoto Review of Southeast Asia," October 1, 2012. https://kyotoreview.org/bahasaindonesia/bunuh-diri-di-kalangan-anak-dan-remaja-indonesia/. 
Tribunnews.com. "Pasangan Kekasih Tewas di Kamar Kos, Kasus Bunuh Diri Keempat Selama Januari 2021 di Tana Toraja." Accessed April 10, 2021.

https://www.tribunnews.com/regional/2021/02/01/pasangan-kekasih-tewas-dikamar-kos-kasus-bunuh-diri-keempat-selama-januari-2021-di-tana-toraja.

Sampe, Naomi. "Meretas Kecakapan Komunikasi Interpersonal Keluarga Kristen Memasuki Era 4.0." BIA': Jurnal Teologi Dan Pendidikan Kristen Kontekstual 2, no. 1 (June 24, 2019): 72-82. https://doi.org/10.34307/b.v2i1.84.

Sanderan, Rannu. "Heuristika dalam Pendidikan Karakter Manusia Toraja Tradisional." BIA': Jurnal Teologi dan Pendidikan Kristen Kontekstual 3, no. 2 (December 19, 2020): 306-27. https://doi.org/10.34307/b.v3i2.213.

Sidjabat, Binsen Samuel. Mengajar secara profesional: mewujudkan visi guru profesional. Bandung: Yayasan Kalam Hidup, 2008.

Simanjuntak, Bungaran Antonius, and Soejidto Sosrodiharjo. Metode Penelitian Sosial (edisi revisi). Jakarta: Yayasan Pustaka Obor Indonesia, 2009.

Sumardiono. Homeschooling : Lompatan Cara Belajar. Jakarta: Elex Media Komputindo, 2007. 